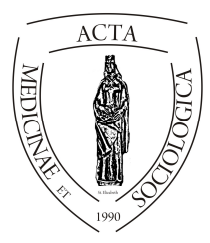

Acta Medicinae et

Sociologica (2019)

Vol. 10. No. 28.

DEBRECEN

FACULTY OF

HEALTH

doi:

\title{
Rizikó-magatartással jellemezhető hallgatók tanulmányi kockázatai
}

\author{
Kovács Klára ${ }^{1}$, Müller Anetta ${ }^{2}$ \\ 1 egyetemi adjunktus, Debreceni Egyetem BTK, Nevelés- és Művelődéstudományi Intézet. \\ 2 \\ egyetemi docens, Debreceni Egyetem GTK, Sportgazdasági és - menedzsment Tanszék.
}

\begin{tabular}{|c|c|}
\hline INFO & ABSTRACT \\
\hline $\begin{array}{l}\text { Kovács Klára } \\
\text { kovacs.klara@arts.unideb.hu }\end{array}$ & $\begin{array}{l}\text { Academic risks of students characterized by risk- } \\
\text { behaviour The aim of our study is to reveal the effectiveness }\end{array}$ \\
\hline $\begin{array}{l}\text { Keywords } \\
\text { health-risk behaviour, } \\
\text { academic achievement, } \\
\text { Higher Education }\end{array}$ & $\begin{array}{l}\text { were curious about the differences between students with } \\
\text { different health-care (risk, inactive and health-conscious) } \\
\text { students in the studied dimensions of educational perfor- } \\
\text { mance in Hungary in the Northern Great Plain region, as well } \\
\text { as in the Transcarpathia, Highlands, Vojvodina, Par-tium and } \\
\text { Transylvania (IESA 2015; N = 2017). In line with our } \\
\text { preliminary assumptions, we can see that there are more } \\
\text { students at risk who attend less than half of the lectures, one } \\
\text { or two or even half of their exams have not been completed, } \\
\text { and less than one hour per lesson, while the latter is the least } \\
\text { characteristic of for health-conscious students. They are } \\
\text { making great efforts to meet their serious study load, but there } \\
\text { are more people who are unable to cope with these difficulties } \\
\text { in the first round and have failed their examinations. In this } \\
\text { way, health-conscious behavior does not constitute supporting } \\
\text { factor in the effectiveness of the study. }\end{array}$ \\
\hline
\end{tabular}

Kulcsszavak
egészségrizikó-
magatartás, tanulmányi
eredményesség, felsőok-
tatás

Absztrakt: Tanulmányunk célja, hogy feltárja a különbözö egészség-magatartással jellemezhető hallgatók tanulmányi ered-ményességét, eredménytelenségét. Arra voltunk kíváncsi-ak, hogy milyen különbségek vannak a különböző egészség-magtartásformával bíró (rizikós, inaktív és egészségtudatos) hallgatók között a tanulmányi teljesítmény vizs-gált dimenzióiban Magyarországon az Észak-alföldi régió, valamint kárpátaljai, felvidéki, vajdasági, partiumi és erdélyi felsőoktatási intézmények hallgatóinak körében egy nemzetközi kutatás adatbázisát elemezve (IESA 2015; N=2017). Elözetes feltételezéseinkkel összhangban azt láthatjuk, hogy a rizikós hallgatók körében többen vannak, akik alig óráik felére járnak be, egy-két, vagy akár vizsgáik felét nem telje- 
sítették és kevesebb, mint napi egy órát készülnek óráikra, míg ez utóbbi a legke-vésbé jellemző az egészségtudatos diákokra. Ök ugyanis nagy erőfeszítéseket tesznek komoly tanulmányi terheik teljesítéséhez, ugyanakkor többen vannak azok is, akik nem tudnak megbirkózni ezekkel a nehézségekkel első körben, és nem sikerült a vizsgájuk. Ily módon az egész-ségtudatos magatartás sem jelent kizárólagos támogató faktort a tanulmányi eredményesség viszonylatában.

A tanulmány a 123847 számú projekt a Nemzeti Kutatási Fejlesztési és Innovációs Alapból biztosított támogatással, a K17 pályázati program finanszírozásában valósult meg. A tanulmány a Bolyai János Kutatási Ösztöndíj és az Emberi Erőforrások Minisztériuma ÚNKP-18-4-DE-61 kódszámú Új Nemzeti Kiválóság Programjának támogatásával készült.

\section{Bevezetés}

A hallgatók egészségmagatartásának vizsgálata több szempontból is fontos. Egyrészt a tanulmányok megkezdése és folytatása, a családtól, korábbi lakókörnyezettől, barátoktól való elszakadás okozta új izgalmas, ámde stresszel terhelt élethelyzet és szülöi kontroll csökkenése nagy mentális és lelki terhet róhat a fiatalokra, másrészt a hallgatói életmódhoz kapcsolódó campus-lét norma- és értékrendszerének hatására nagyobb valószínüséggel fordulhatnak elő bizonyos egészségkárosító magatartásformák a fiatalok körében, föként nagy mennyiségü alkoholfogyasztás a nem egyetemista populációhoz képest (Von Ah és mtsai 2004; Hunt és Eisenberg 2010; O'Malley és Johnston 2002). A nagyivászat és kábítószer-használat pedig olyan más kockázatokkal jár együtt, mint a közúti balesetek, nem biztonságos szexuális magatartás, agresszív viselkedés, verekedés, öngyilkosság, amelyek veszélyeztethetik az egyetem/föiskola befejezését és későbbi függőség kialakulásához vezethetnek (Cranford és mtsai 2009; Wechsler és mtsai 1995; Miller és mtsai 2007).

Tanulmányunk célja, hogy feltárja a különböző egészség-magatartással jellemezhető hallgatók tanulmányi eredményességét, eredménytelenségét. Arra voltunk kíváncsiak, hogy milyen különbségek vannak a különböző egészségmagtartásformával bíró (rizikós, inaktív és egészségtudatos) hallgatók között a tanulmányi teljesítmény vizsgált dimenzióiban (extrakurrikuláris munka és emelletti elköteleződés, tanulmányok melletti kitartás, illetve a tanulmányi intenzitás különböző indikátoraiban). Kutatási kérdésünk, hogy vajon az egészségmagatartás szempontjából rizikót vállaló hallgatók (akik rendszeresen dohányoznak, gyakrabban fogyasztanak nagy mennyiségü alkoholt, s leginkább jellemző rájuk a kábítószerezés is) a tanulmányi előmenetelükben is kockázatvállalóbbak-e, hiszen ha rosszabbul teljesítenek a tanulmányaikat illetően, nagyobb valószínüséggel morzsolódhatnak le. Ezzel szemben vajon az egészségtudatossággal jellemezhető hallgatók esetében ez a pozitív, elkötelezett magatartás megjelenik-e a tanulmányi pályafutásuk tekintetében is? 


\section{Tanulmányi eredményesség és befolyásoló tényezői}

Kutatásunk elméleti hátterének legfontosabb alapját az ún. Jéghegy-modell adja (OECD 2012). A modell azokat az iskolai, tanulmányi, szocio-kulturális és egyéni tényezőket igyekszik összegyüjteni, melyek tanulmányi eredménytelenséghez és végső soron pedig egy diák lemorzsolódásához vezethetnek. A jéghegy látható, s jól vizsgálható részét két tényező alkotja: 1. a legkönnyebben vizsgálható dimenzió a tanulmányi teljesítmény, hiszen a rosszabb iskolai eredmények a lemorzsolódás legnyilvánvalóbb előrejelzői. Vizsgálatunkban ilyen eredményesség mutatók az extrakurrikuláris munka és emelletti elköteleződés, tanulmányok melletti kitartás, illetve a tanulmányi intenzitás. Ugyanakkor a modell hangsúlyozza, hogy noha ezek a tényezők mérhetők a legkönnyebben, de a tanulmányi teljesítményt számos más háttértényező befolyásolja, melyek vizsgálata legalább ennyire fontos. Ilyenek többek között a diákok attitüdei a tanulmányokhoz kapcsolódóan. Így a 2. viszonylag könnyen vizsgálható prediktor a diákok magatartása, viselkedése: ide tartoznak mindazok az attitüdök és értékek, melyek meghatározzák a diákok választását és döntését, hogy elkötelezik-e magukat a tanulmányok minél sikeresebb elvégzése mellett (akadémiai és szociális viszonylatban egyaránt), vagy inkább a deviáns magatartást választják. Ez utóbbihoz tartoznak a norma- és szabályszegő viselkedés mellett az egészségre káros magatartásformák is, melyek hatását tanulmányunkban is vizsgáljuk. Kutatásunkban e két dimenzió összefüggéseit tárjuk fel hozzájárulva a modell mélyebb megértéséhez.

A tanulmányi eredményességet sokféle kontextusban vizsgálták már. Vannak olyan irodalmak, melyek a tanulmányi eredményességet közvetlenül meghatározó tanulási folyamat egy-egy momentumára koncentrálva számolnak be kutatási eredményekről. Például ilyen vizsgált elem a tanulási motiváció, melynek kutatása a hetvenes évektől vett lendületet (Morstain és Smart 1977; Wolfgang és Dowling 1981; Engler 2014). A tanulmányi teljesítménnyel kapcsolatos vizsgálatok sok esetben fókuszáltak a tanuló előképzettségére vagy előzetes tudásszintjére, a tanulásra fordított időre, a felkészülésre vagy az extrakurrikuláris tevékenységekre (kiselőadás, házi dolgozat, önkéntes munka). Az önkéntesség növeli az akadémiai eredményességet (1. Fényes és Markos, 2016; Fényes és mtsai, 2015; Smith, 1994), illetve segítheti a tanulmányi kreditek megszerzését a felsőoktatásban (Mueller 1975).

Más kutatások az óralátogatás és tanulmányi eredményesség pozitív kapcsolatát mutatták ki, illetve megint mások az iskolai hiányzás vagy óráktól való távolmaradás és sikertelenség összefüggéseit elemezték. A tanulók felkészülésére jellemző módszerek (Veroszta 2009), eszközök és a felkészülési idő is a vizsgálatok tárgya sok kutatásban. A tanulási eredményességet a tanulást támogató eszközök (MOOC kurzusok, digitális repozitóriumok (Czeglédi 2017a)), könyvtári szolgáltatások megléte is pozitív irányba befolyásolhatja (Czeglédi 2017b; Czeglédi 2018; Kozsla és mtsai 2014). Engler (2014) egyetemisták körében végzett kutatásából kiderül, hogy akiknek a tanulmányi eredményessége rosszabb volt, a következő hátráltató tényezőket nevesítették: sok időt igényel a tanulmányi ügyek intézése vagy a könyvek beszerzése (vásárlással vagy a könyvtárból). 
Számos kutatás a külső tényezők vagy külső környezet hatását vizsgálta mint a tanulás eredményességét befolyásoló tényezőket: pl. családi háttér, kortárscsoportok, tantervek, informális tanulási környezet (Forray és Juhász 2009) vagy a lakó- és az iskolai környezetet. A tanulmányi eredményesség vizsgálatában több elemzés is modellezi az akadémiai eredményesség és a szocio-demográfiai háttér lineáris összefüggését (Epple és mtsai 1998; Hsieh és mtsai 2006; Bourdieu 1977; DiMaggio 1982).

A különböző iskolákból érkező egyetemisták tanulmányi eredményessége kapcsán Engler (2014) megállapította, hogy a gimnáziumból érkezők a jobb tanulmányi eredményekkel rendelkezők csoportját alkotják, ám a családi háttérváltozók hatását az akadémiai eredményességben az észak-alföldi régiós mintán nem tudta kimutatni. A tanulás eredményességében a gender kutatások (Leathwood 2006; Koncz 2006; Kopp 2010; Engler, 2012; Engler 2014; Fényes 2010) a nők szerepét, helyzetét és motivációit vizsgálják, hasonlítják a férfiak teljesítményéhez és sok esetben a nők perzisztenciáját és eredményességét igazolják. Shery és mtsai 2011-ben az egyetemista sportolók körében azt tapasztalták, hogy a férfi sportolók alacsonyabb arányban (52\%) diplomáztak, mint a női sportolók (68\%). Ez a kutatás is a nők eredményesebb voltát igazolta.

Több kutatás vizsgálta az élsportolók tanulmányi fejlődését és a sportolói teljesítmény közötti kapcsolatot. Miller (2000) a sportolók oldaláról vizsgálva arra a megállapításra jutott, hogy esetükben a követelmények teljesítéséhez a megfelelö módszerek és stratégiák alkalmazása szükséges. Aquilina (2013), Mckenna és mtsai (2004), Kovács (2015a; 2015b) és Lenténé (2017) vizsgálata során azt találta, hogy a sportolók képesek a tanulmányokban és a sportban is kiemelkedő eredményeket elérni tudatos időmenedzsmenttel és a prioritások megfelelő egyensúlyozásával. Lenténé (2017) ugyanakkor kiemelte, hogy a prioritások is változhatnak annak függvényében, hogy a sportolók mikor, melyik területre helyezik inkább a hangsúlyt. Lenténé a sportolói minta kreditátlagában jobb tanulmányi teljesítményt igazolt a nem sportolókhoz képest. Egy belga egyetemi kutatás is azt bizonyítja, hogy a sportteljesítmény és a tanulás összehangolható, ám csak akkor, ha a felsőoktatási intézmények számára is kulcsfontosságú a sportolók tanulásának támogatása (De Knop és mtsai 1999). Mindezek az eredmények felhívják a figyelmet arra, hogy a témánk szempontjából releváns egészségtudatosabb hallgatók (akik rendszeresen, sőt akár versenyszerüen sportolnak) jó, vagy akár kiemelkedő tanulmányi eredményekre képesek.

A rizikó-magatartás és tanulmányi eredményesség/eredménytelenség viszonylatában a szerfogyasztás és lemorzsolódás között találunk összefüggéseket: ebben az esetben a nagy mennyiségü alkoholfogyasztás, rendszeres lerészegedés mint deviáns magatartás játszik szerepet, ami növeli a lemorzsolódás veszélyét és megerősíti a kapcsolatot a normaszegő kortárscsoportokkal egy norvég, középiskolások körében végzett felmérés szerint (Wichstrøm 1998). A felsőoktatási hallgatók esetében egyes elemzések a bulizás (és az ezzel együtt járó alkohol- és drogfogyasztás) és lemorzsolódás összefüggésében azt emelik ki, hogy ez egyfajta pótcselekvés, amikor egy hallgató „elindul lefelé a lejtőn”: a sikertelen kurzusok, tárgyak, vizsgák teljesítése miatt egyre inkább elkeserednek, kiábrándulnak, egyre kevésbé tartják fontosnak a tanulást, s olyan pótcselekvéseket keresnek, mint a bulizás vagy éppen a fizetett munka, amik elterelik a figyelmüket a tanulmányokhoz kapcsolódó kudarcokról (Daley 2010). 


\section{Módszer}

Az elemzésekhez a Felsőoktatási Kutató és Fejlesztő Intézet (CHERD-H) egy öt ország (Magyarország, Szlovákia, Ukrajna, Románia, Szerbia) felsőoktatási intézményeinek hallgatóit vizsgáló kérdőíves felméréséből származó adatbázisát használtuk fel (IESA, N=2017). A vizsgált intézmények: Babes-Bolyai Tudományegyetem (és kihelyezett karai/tagozatai), Debreceni Egyetem, Debreceni Református Hittudományi Egyetem, Munkácsi Állami Egyetem, Nyíregyházi Főiskola, Partiumi Keresztény Egyetem, II. Rákóczi Ferenc Kárpátaljai Magyar Főiskola, Sapientia Erdélyi Magyar Tudományegyetem, Ungvári Nemzeti Egyetem, Nagyváradi Egyetem. A mintavételi keret meghatározása az intézmények adatszolgáltatása alapján történt. A karok és intézmények hallgatószámával arányosan alakítottuk ki az elemszámot, ebböl kifolyólag természetesen sokkal több magyarországi hallgató van, mint határon túli. Az alap- és az osztatlan képzés 2. évfolyamán 20 százalékos, a mesterképzés 1. évfolyamán és az osztatlan képzés 4. évfolyamán pedig 50 százalékos mintát terveztünk. A diákokat csoportosan, egyetemi/föiskolai kurzusokon kerestük meg. A véletlenszerüség érvényesülését az e csoportok random módon történő kiválasztása biztosította (Pusztai és Ceglédi 2015). A kutatásba bevont hazai intézményekés a régió sajátossága, hogy a hallgatók legalább 15 százaléka hátrányos helyzetünek tekinthető a felvételi során hátrányos helyzetért járó többletpontok igénylése alapján (Hegedüs 2016).

Az egészségrizikó-magatartás négy dimenzióját vizsgáltuk: a dohányzás, a nagy mennyiségü alkohol- és drogfogyasztás, illetve a sportolás gyakoriságát az elmúlt évben (négy item). ${ }^{1}$ A válaszlehetőségeket 0-100 skálává kódoltuk át, ahol 0 jelölte, ha egyáltalán nem jellemzők ezek a magatartásformák a válaszadóra, 100 pedig, ha napi rendszerességgel végzi $\left(M_{\text {dohányzás }}=25,88, \quad S D=37,74 ; \quad M_{\text {nagyivászat }}=29,72\right.$, $\left.\mathrm{SD}=28,56 ; \mathrm{M}_{\text {drog }}=3, \mathrm{SD}=12,97, \mathrm{~N}=1961 ; \mathrm{M}_{\text {sport }}=55,22, \mathrm{SD}=33,06\right)$.

$\mathrm{Az}$ egészség-magatartást mérő változók bevonásával klaszterelemzéssel három hallgatói csoportot különítettünk el: rizikómagatartással jellemezhető $(n=512$, $26,1 \%)$, inaktív ( $n=645,32,9 \%)$ és egészségtudatos hallgatók $(n=804,41 \%)$. Az első csoport tagjai a legnagyobb gyakorisággal nyúlnak egészségkárosító szerekhez, $\mathrm{s}$ legkevésbé jellemzős rájuk a sporttolás, míg a második csoportban lévők nem isznak, dohányoznak, drogoznak olyan gyakorisággal, de szinte soha nem végeznek sporttevékenységet, az utolsó csoportba tartozókra pedig legkevésbé jellemzők a rizikómagatartás-formák, viszont ők végeznek legrendszeresebben testedzést.

A tanulmányi eredményesség méréséhez több változót is felhasználtunk. Megnéztük az extrakurrikuláris tevékenységeket (van-e TDK-ja, részt vesz-e kutatócsoportban, tehetséggondozó programban, részesült-e különböző ösztöndíjakban,

\footnotetext{
${ }^{1}$ Milyen gyakran fordult elő az elmúlt egy évben, hogy ittas volt, berúgott/dohányzott/drogot használt. Válaszlehetőségek: 1. szinte minden nap; 2. hetente 1-2 szer (hétvégenként); 3. havonta néhányszor; 4. egy - két havonta; 5. ennél ritkábban; 6. egyszer sem. Az elmúlt néhány hónapban a testnevelés kurzuson kívül milyen gyakran végeztél olyan intenzív sporttevékenységet, amely legalább 45 percig tartott? Válaszlehetőségek: 1. soha; 2. évente 1-2szer; 3. havonta 1-2-szer; 4. havonta többször; 5. hetente 1-2-szer; 6. hetente háromszor vagy többször.
} 
van-e magántanítványa, felső- vagy középfokú nyelvvizsgája stb.), azt, hogy mennyire elkötelezett az órai munkában, illetve különböző feladatok teljesítésében, melyet az tanulás melletti elköteleződésnek nevezünk (milyen gyakran szól hozzá az órai beszélgetésekhez, kérdez, konzultál az órai témákról, dolgozik együtt hallgató társaival, oktatóival stb.), mennyire kitartó abban, hogy teljesítse a tanulmányi kötelezettségeit a felmerülő problémák ellenére, illetve minél jobb teljesítményt nyújtson (perzisztencia).

A szakirodalomból kiindulva kifejezetten kíváncsiak voltunk, hogy milyen mértékben tesznek eleget a tanulmányi kötelezettségeiknek, milyen az óralátogatási, vizsgahatékonyságuk, milyen mértékben voltak képesek abszolválni a különböző kurzusok teljesítéséhez szükséges feladatokat. A tanulmányi intenzitás méréséhez megnéztük, hogy milyen arányban látogatták az óráikat, tették le vizsgáikat ismétlés nélkül, mennyit időt töltöttek átlagosan az órákra való felkészülésre, illetve kb. hány szakirodalmat, olvastak el, beadandót készítettek, hány olyan szemináriumuk, vizsgájuk volt, ami nagy erőfeszítést jelentett a számukra.

Az extrakurrikuláris tevékenységekből indexet készítettünk, mivel nagyon magas azon hallgatók aránya, akik nemmel válaszoltak a legtöbb kérdésre ( 0 -18 pont), a tanulás melletti elköteleződés és a perzisztencia itemeiből pedig fökomponenselemzéssel két főkomponenst készítettünk, melynek fökomponens-súlyait 0-100 fokú skálává alakítottunk át ( 0 ha egyáltalán nem jellemző rá az órai, vagy órán kívüli pluszmunka, illetve hogy kitartó lenne a tanulmányai mellett, 100 pedig, ha teljes mértékben). ${ }^{2}$ Mivel a tanulmányi intenzitás egyes indikátorai önmagukban is nagyon fontos eredményesség-mutatók, így ezeket nem vontuk össze egy változóvá

Tehát összességében a tanulmányi eredményesség vizsgálatához a következő dimenziókat és indikátorokat használtuk fel:

1. extrakurrikuláris tevékenységek (index 0-18 pontig),

2. tanulás melletti elköteleződés (0-100 fokú főkomponens),

3. perzisztencia, kitartás (0-100 fokú főkomponens),

4. tanulmányi intenzitás: óralátogatás, órákra való készülés intenzitása, vizsgahatékonyság.

\section{Eredmények}

Az extrakurrikuláris tevékenységeket illetően három területen értek el kiemelkedő eredményt a hallgatók, 40\% fölött jelezték, hogy van magyar nyelvü önéletrajzuk, részesültek már egyéb tanulmányi ösztöndíjban (ennek mértékétől függetlenül), a legtöbben azt, hogy van középfokú komplex nyelvvizsgájuk (48\%). A hallgatók egyötödének volt már magántanítványa, részesült már érdemösztöndíjban, van saját szellemi találmánya. Csupán minden 10. hallgatónak van legalább egy publikációja, adott elő konferencián, s a legkevesebben, 5\% alatt rendelkezik valamilyen tudomá-

\footnotetext{
${ }^{2}$ Tanulás melletti elköteleződés fökomponense: $\mathrm{KMO}=, 902$; Magyarázott variancia: 50,2\%. Perzisztencia fökomponense: $\mathrm{KMO}=, 899$, magyarázott variancia: $51,85 \%$
} 
nyos ösztöndíjjal (DETEP-en kívül), illetve volt már legalább egyszer köztársasági ösztöndíjas (1. ábra).

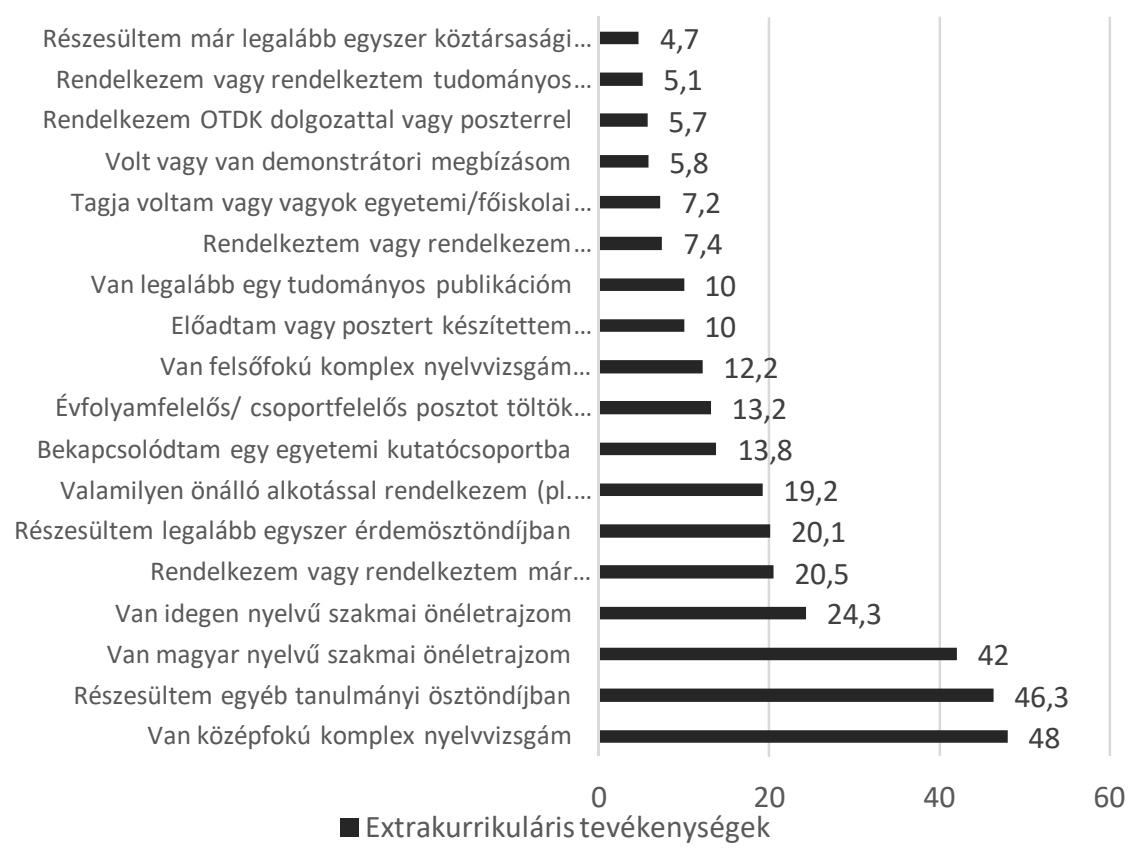

Forrás: IESA 2015 (N=2017).

1. ábra. A különböző extrakurrikuláris aktivitásban részt vett hallgatók aránya.

A hallgatók többsége, 44,7\%-a gyakran dolgozott együtt hallgatótársaival az órán, $38,3 \%$-a pedig órán kívül is.

A perzisztencia esetében azt láthatjuk, hogy a hallgatók legnagyobb arányban teljes mértékben egyet értenek azzal, hogy nagyon elszántak tanulmányaik befejezését illetően $(57,3 \%)$, minél jobb eredményeket szeretnének elérni (52,4\%), inkább egyetértenek azzal, hogy képesek figyelni az órákon (58,6\%) és felkészülni a vizsgákra $(57,4 \%)$, a diákok 52,8\%-a nagy mértékben részt vesz az előadásokon/szemináriumokon.

A tanulmányi intenzitáshoz kapcsolódóan azt láthatjuk, hogy a hallgatók többsége 1-4 kötelező $(36,9 \%)$ és ajánlott $(48,7 \%)$ szakirodalmat olvasott el az előző félévben, míg 10,8 és 23,7\%-uk egyet sem. Több mint húsz kötelezöt pedig 12, illetve ajánlottat 3,2\%. A hallgatók 52,3\%-nak volt 1-4 olyan vizsgája, 41,7\%-nak pedig olyan gyakorlata, szemináriuma, amire való felkészülés nagy erőfeszítést igényelt a részükről. Döntő többségük, 64,3\% óráik 80-100\%-ra bejártak, és elsőre sikerült minden vizsgája 49,8\%-nak, viszont 1,4\% gyakorlatilag nem látogatta az óráit, 4,8\%-nak pedig egy vizsgát sem sikerült letennie elsőre. A válaszadók $26 \%$-a három óránál valamivel kevesebbet vagy többet készülnek az óráikra, minden ötödik kevesebbet, mint két órát, 4,9\% pedig kevesebb, mint fél órát (2. ábra). 


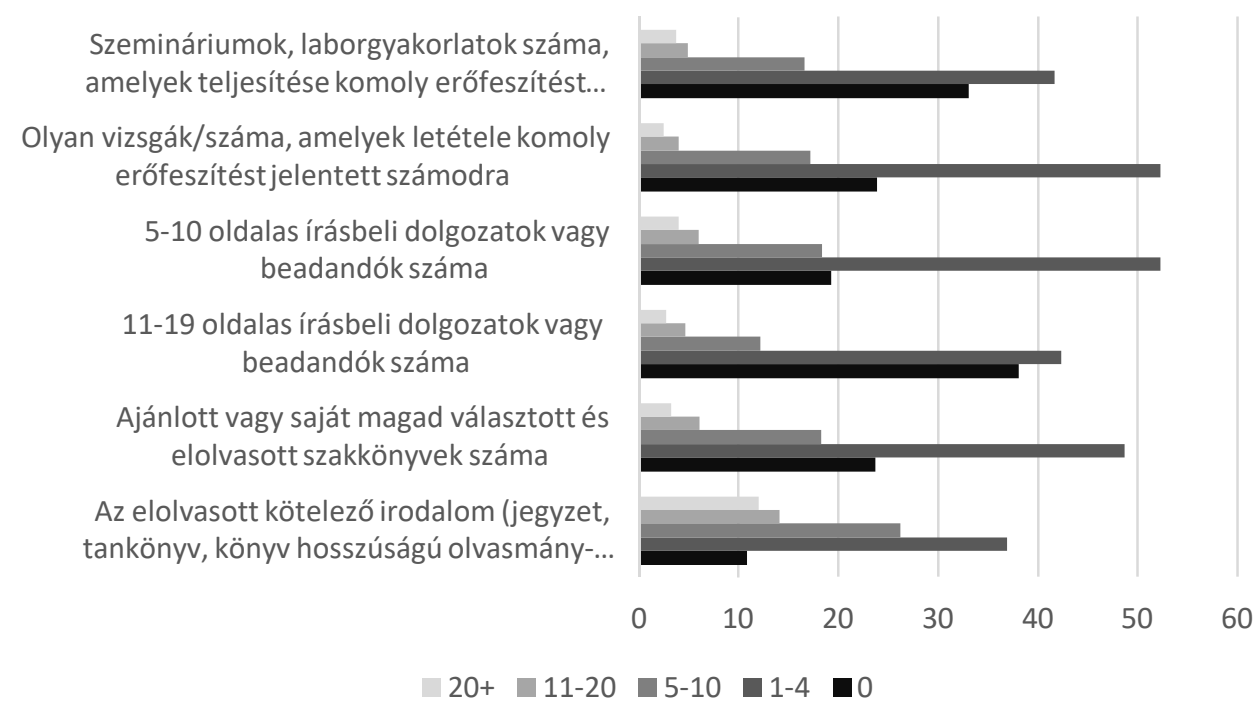

Forrás: IESA 2015 (N=2017).

2. ábra. A tanulmányi intenzitás indikátorainak megoszlása a hallgatók körében.

Az egészség-magatartás klaszterek hallgatóinak társadalmi háttere

Kutatásunk első részében megvizsgáltuk, hogy milyen társadalmi háttérrel jellemezhetők az egészség-magatartási formák alapján elkülönülö hallgatói csoportjaink. A rizikómagatartással jellemezhető hallgatók körében felülreprezentáltak a férfiak, a jobb anyagi helyzetben lévő és magas iskolai végzettséggel jellemezhető szülök gyerekei. Noha a serdülö- és fiatal felnőtt korúak körében készült vizsgálatok alapvető tanulsága szerint a kemény társadalmi háttérváltozók kevésbé befolyásolják, magyarázzák a szerfogyasztást és a rizikómagatartást (Hanson és Chen 2007; Steptoe és mtsai 2002; Pikó, Brassai és Fitzpatrick 2013), esetünkben mégis azt láthatjuk, hogy elsősorban a magasabb társadalmi státuszú családok gyermekei nyúlnak leggyakrabban egészségkárosító szerekhez. Vannak tanulmányok, melyek a szocioökonómiai háttér és az alkoholfogyasztásra, illetve dohányzásra fordított jövedelem alakulását vizsgálják. Jaja (2017) megállapítja, hogy a jövedelem növekedésével többet fordítunk ilyen cikkekre, ám jövedelemarányosan a szegény és a társadalmilag hátrányos helyzetủ háztartások többet fordítanak az ilyen árukra másokkal szemben. A férfiak dominanciája a rizikómagatartásban számos korábbi kutatásban is igazolódott (Cranford, Eisenberg és Serras 2009; Steptoe és mtsai 2002; Emmons és mtsai 1998; Aszmann 1997; Hunt és Eisenberg 2010). Korábbi kutatási eredményeinkkel és elemzéseinkkel összhangban az erdélyi - partiumi, illetve vajdasági, rosszabb anyagi helyzetben lévő, elsősorban női hallgatók felülreprezentáltak az inaktív életmóddal jellemezhető diákok körében (Kovács 2013; Kovács 2015c; Kovács et al. 2017), de azt is láthatjuk, hogy az e csoportba tartozó hallgatók többségének középfokú végzettségü az édesanyja, melynek szintén befolyásoló szerepe van az egészség-magatartásban. Az egészségtudatos hallgatók körében felülreprezentáltak a kárpátaljai és felvidéki hallgatók. 


\begin{tabular}{|l|l|c|c|c|}
\hline & & Rizikós & Inaktív & Egészségtudatos \\
\hline \multirow{4}{*}{$\begin{array}{l}\text { ország } \\
(\mathrm{p}=0,001, \mathrm{~N}=1957)\end{array}$} & Magyarország & 62,6 & 55,7 & 61,9 \\
\cline { 2 - 5 } & Románia & 16,8 & $\mathbf{2 0 , 2}$ & 13,1 \\
\cline { 2 - 5 } & Ukrajna & 9 & 12 & $\mathbf{1 4 , 1}$ \\
\cline { 2 - 5 } & Szerbia & 2,3 & $\mathbf{4 , 4}$ & 2,9 \\
\cline { 2 - 5 } & Szlovákia & 9,2 & 7,8 & $\mathbf{8 , 1}$ \\
\cline { 2 - 5 } & Összesen & $100 \%$ & $100 \%$ & $100 \%$ \\
\hline \multirow{4}{*}{$\begin{array}{l}\text { Nem } \\
(\mathrm{p}=0,000, \mathrm{~N}=1901)\end{array}$} & Nö & 66,5 & $\mathbf{7 9 , 7}$ & 72 \\
\cline { 2 - 5 } & Férfi & $\mathbf{3 3 , 5}$ & 20,3 & 28 \\
\cline { 2 - 5 } & Összesen & $100 \%$ & $100 \%$ & $100 \%$ \\
\hline \multirow{3}{*}{$\begin{array}{l}\text { Objektív anyagi helyzet } \\
(\mathrm{p}=0,002, \mathrm{~N}=1961)\end{array}$} & Átlag alatt & 35,2 & $\mathbf{4 5 , 4}$ & 40,9 \\
\cline { 2 - 5 } & Átlag felett & $\mathbf{6 4 , 8}$ & 54,6 & 59,1 \\
\cline { 2 - 5 } & Összesen & $100 \%$ & $100 \%$ & $100 \%$ \\
\hline \multirow{2}{*}{$\begin{array}{l}\text { Anya iskolai végzettsége } \\
(\mathrm{p}=0,015, \mathrm{~N}=1868)\end{array}$} & Alapfokú & 5,3 & 6,6 & 6 \\
\cline { 2 - 5 } & Középfokú & 61,5 & $\mathbf{6 9 , 3}$ & 63,8 \\
\cline { 2 - 5 } & Felsőfokú & $\mathbf{3 3 , 2}$ & 24,1 & 30,2 \\
\cline { 2 - 5 } & Összesen & $100 \%$ & $100 \%$ & $100 \%$ \\
\hline
\end{tabular}

*Az vastagon szedett értékek arra utalnak, hogy a táblázat azon cellájába jóval többen kerültek, mint amennyi véletlen elrendeződés esetén várható lett volna.

Forrás: IESA 2015

1. táblázat. Az egészség-magatartás alapján elkülönülő klaszterek hallgatóinak szociokulturális háttere.

\section{Egészségmagatartás és tanulmányi eredményesség}

Az egészség-magatartás és a tanulmányi eredményesség összefüggéseinél csak a tanulmányi intenzitás egyes aldimenzióiban találtunk szignifikáns különbségeket. Sem az extrakurrikuláris tevékenységekben, sem a tanulás melletti elköteleződésben, sem a perzisztencia fökomponensében nem találtunk szignifikáns különbségeket az egyes klasztercsoportok között. A szakirodalommal és feltételezéseinkkel összhangban az egészségtudatos hallgatók között számos kérdésben felülreprezentáltak a legkiválóbb eredményekkel jellemezhető hallgatók: a legmagasabb arányban találhatunk körükben olyan diákokat, akik több, mint 20 ajánlott szakkönyvet olvastak az elmúlt tanévben $(4,2 \%), 5-10$ oldalas beadandót készítettek $(5,5 \%)$, nehézséget okozó tárgyat teljesítettek (4,9\%, de 6,4-uknak 11-20 ilyen tárgyuk volt), 62,2\%-uk szinte minden órán részt vett. Ugyanakkor meglepő, hogy mindezek ellenére vagy mellett a vizsgákkal nem tudtak olyan jól megbirkózni, mivel körükben a legmagasabb a másik két hallgatói csoporthoz viszonyítva azok aránya, akiknek egy vizsgája sem sikerült elsőre (6,4\%). Ez a problematika, csakúgy, mint a sportban, felveti a teljesítőképesség és a teljesítőkészség fogalmi értelmezését (Borbély és Müller 2008). A teljesítőképességet befolyásolja, hogy készült a vizsgákra, a tanulásra fordított idő, a kontakt órákon való részvétel, a beadandó dolgozatok alapos elkészítése, aktív órai jelenlét. A teljesítőkészség dimenzióját meghatározza, hogy a tanultakat mennyire tudja előhívni vizsgakörülmények között. A 
teljesítőkészség esetében a vizsgától való félelem, stressz is befolyásolja, hogy a tanult ismereteket mennyire képes tét-helyzetben realizálni. Ha magas a stressz szintje, ez gátolja a jó teljesítményt, ha túl alacsony és apatikus a hallgató, ez is negatívan hat a teljesítményre. Az optimális stressz-szint tehát nélkülözhetetlen a hallgatói eredményességben.

A rizikómagatartással jellemezhető hallgatók ugyanakkor több dimenzió tekintetében is a legrosszabb eredményt érték el. A csoport tagjainak alig fele nyilatkozott úgy, hogy az órák 80-100\%-án részt vett, s csupán a csoport egyötöde, hogy naponta több, mint egy órát készül az órákra, míg 14\%-uk kevesebbet, mint egy órát. Körükben alulreprezentáltak azok a hallgatók, akiknek minden vizsgájuk elsőre sikerült (41,3\%) viszont azok is, akiknek nem volt sikeres vizsgája $(2,9 \%), \mathrm{s}$ felülreprezentáltak, akinek a kb. a fele (9\%). A vizsgaeredmények azt mutatják, hogy az órai aktivitás és az órákra való készülés intenzitása nem feltétlenül eredményezi, vagy áll összefüggésben a magas vizsgahatékonysággal. Az inaktív hallgatók a tanulmányi intenzitás, teljesítmény két klasszikus, talán legidőigényesebb mutatójában értek el kiemelkedő eredményt: a három csoport viszonylatában körükben a legmagasabb az óralátogatás (az órák 80-100\%-án részt vett a csoport $70,9 \%$-a), és a vizsgahatékonyság (minden vizsgáját elsőre letette a csoport hallgatóinak 55,6\%-a) (2. táblázat).

\begin{tabular}{|c|c|c|c|c|}
\hline & & Rizikós & Inaktív & Egészségtudatos \\
\hline \multirow{6}{*}{$\begin{array}{l}\text { Ajánlott vagy saját } \\
\text { magad választott és } \\
\text { elolvasott szakkönyvek } \\
\text { száma (p=0,020, } \\
\mathrm{N}=1850)\end{array}$} & 0 & 24,3 & 26,1 & 21,1 \\
\hline & $1-4$ & 45,8 & 51,3 & 48,6 \\
\hline & $5-10$ & 20,5 & 14,2 & 20,3 \\
\hline & $11-20$ & 6,7 & 6 & 5,8 \\
\hline & $20+$ & 2,6 & 2,4 & 4,2 \\
\hline & Összesen & $100 \%$ & $100 \%$ & $100 \%$ \\
\hline \multirow{6}{*}{$\begin{array}{l}5 \text {-10 oldalas írásbeli } \\
\text { dolgozatok vagy be- } \\
\text { adandók száma } \\
(\mathrm{p}=0,014, \mathrm{~N}=1818)\end{array}$} & 0 & 16,8 & 19 & 21,2 \\
\hline & $1-4$ & 52,4 & 56,4 & 48,8 \\
\hline & $5-10$ & 19,5 & 17 & 18,8 \\
\hline & $11-20$ & 7,4 & 5,4 & 5,7 \\
\hline & $20+$ & 3,9 & 2,1 & 5,5 \\
\hline & Összesen & $100 \%$ & $100 \%$ & $100 \%$ \\
\hline \multirow{6}{*}{$\begin{array}{l}\text { Szemináriumok, labor- } \\
\text { gyakorlatok száma, } \\
\text { amelyek teljesítése } \\
\text { komoly erőfeszítést } \\
\text { jelentett számodra } \\
(\mathrm{p}=0,019, \mathrm{~N}=1838)\end{array}$} & 0 & 33,2 & 34,8 & 31,5 \\
\hline & $1-4$ & 39,1 & 43 & 42,4 \\
\hline & $5-10$ & 19,7 & 16 & 14,9 \\
\hline & $11-20$ & 4,1 & 3,9 & 6,4 \\
\hline & $20+$ & 3,9 & 2,1 & 4,9 \\
\hline & Összesen & $100 \%$ & $100 \%$ & $100 \%$ \\
\hline \multirow{7}{*}{$\begin{array}{l}\text { Ebben a tanévben, egy } \\
\text { átlagos héten az óráid } \\
\text { hány százalékára jártál } \\
\text { be? }(\mathrm{p}=0,000, \mathrm{~N}=1868)\end{array}$} & $80-100 \%$ & 51,4 & 70,9 & 67,2 \\
\hline & $60-80 \%$ & 31,2 & 19,3 & 23,9 \\
\hline & $40-60 \%$ & 10,6 & 5,5 & 4,7 \\
\hline & $20-40 \%$ & 4 & 1,6 & 1,8 \\
\hline & $0-20 \%$ & 2 & 1,1 & 1,2 \\
\hline & nem tudom & 0,8 & 1,6 & 1,2 \\
\hline & Összesen & $100 \%$ & $100 \%$ & $100 \%$ \\
\hline
\end{tabular}




\begin{tabular}{|c|c|c|c|c|}
\hline \multirow{7}{*}{$\begin{array}{l}\text { Az előző félévben hány } \\
\text { olyan vizsgád volt, amit } \\
\text { az első (halasztás nél- } \\
\text { kül) alkalomkor sikerült } \\
\text { letenned? ( } \mathrm{p}=0,000, \\
\mathrm{~N}=1817 \text { ) }\end{array}$} & mind & 41,3 & 55,6 & 51 \\
\hline & $\begin{array}{l}\text { mind, egyet- } \\
\text { kettőt kivéve }\end{array}$ & 37,8 & 28 & 28,3 \\
\hline & $\begin{array}{l}\text { kb. vizsgáim } \\
\text { fele }\end{array}$ & 9 & 4 & 4,8 \\
\hline & $\begin{array}{c}\text { Kevesebb, mint } \\
\text { a fele }\end{array}$ & 2,5 & 2 & 2,3 \\
\hline & egy sem & 2,9 & 4 & 6,4 \\
\hline & nem tudom & 6,5 & 6,5 & 7,2 \\
\hline & Összesen & $100 \%$ & $100 \%$ & $100 \%$ \\
\hline \multirow{7}{*}{$\begin{array}{l}\text { Egy átlagos napon hány } \\
\text { órát készülsz az óráidra } \\
\text { (tanulás, olvasás, be- } \\
\text { adandó készítése)? } \\
(\mathrm{p}=0,024, \mathrm{~N}=1852)\end{array}$} & több, mint 3 óra & 19,7 & 27,8 & 28,2 \\
\hline & $\begin{array}{l}\text { kevesebb, mint } \\
3 \text { óra }\end{array}$ & 25,8 & 26,2 & 26,6 \\
\hline & $\begin{array}{l}\text { kevesebb, mint } \\
2 \text { óra }\end{array}$ & 22,4 & 17,4 & 19,1 \\
\hline & $\begin{array}{l}\text { kevesebb, mint } \\
1 \text { óra }\end{array}$ & 14 & 11,9 & 9,8 \\
\hline & $\begin{array}{l}\text { kevesebb, mint } \\
\text { fél óra }\end{array}$ & 6,3 & 4,6 & 4,3 \\
\hline & nem tudom & 11,8 & 12,2 & 12,1 \\
\hline & Összesen & $100 \%$ & $100 \%$ & $100 \%$ \\
\hline
\end{tabular}

*A félkövér és dőlt formázással közölt értékek arra utalnak, hogy a táblázat azon cellájába jóval többen, a félkövérrel jelöltek pedig arra, hogy kevesebben kerültek, mint amennyi véletlen elrendeződés esetén várható lett volna.

Forrás: IESA 2017.

2. táblázat. Az egészség-magatartás mentén elkülönülő klaszterek hallgatóinak aránya a tanulás intenzitása különböző dimenzióiban.

\section{Összegzés és konklúzió}

Tanulmányunkban feltártuk az egészség-magatartási formák és a tanulmányi eredményesség különböző dimenziói közötti összefüggéseket Magyarországon az Északalföldi régió, valamint kárpátaljai, felvidéki, vajdasági, partiumi és erdélyi felsőoktatási intézmények hallgatóinak körében $(\mathrm{N}=2017)$. Az eredményesség vizsgálatához megnéztük a hallgatók extrakurrikuláris munka és taanulási elköteleződésének, a tanulmányok melletti kitartásának, illetve a tanulmányi intenzitásuk mértékét, s öszszehasonlítottuk ezen dimenziók mentén az egészségmagatartási formák alapján elkülönülő rizikó-magatartással jellemezhető, inaktív és egészségtudatos diákokat. Előzetes feltételezéseinkkel összhangban azt láthatjuk, hogy a rizikós hallgatók körében többen vannak, akik óráik alig felére járnak be, egy-két, vagy akár vizsgáik felét nem teljesítették és kevesebb, mint napi egy órát készülnek óráikra, míg ez utóbbi a legkevésbé jellemző az egészségtudatos diákokra. Ők az átlagosnál nagyobb erőfeszítéseket tesznek a tanulmányi követelmények teljesítésében: felülreprezentáltak körükben azok, akik több szakirodalmat olvasnak, beadandót készítenek. Ugyanakkor az is megfigyelhető, hogy sokan nem tudnak megbirkózni ezekkel a 
nehézségekkel első körben, és nem sikerül a vizsgájuk, ami arra utal, hogy az egészségtudatos magatartás sem jelent egyértelmü pozitívumot a tanulmányi eredményesség viszonylatában. Ennek hátterét, az esetleges kontextuális hatások szerepét egy következő vizsgálatban szeretnénk feltárni.

A lemorzsolódás komoly probléma hazánkban, hiszen magas (35\%) azoknak a hallgatóknak az aránya, akik valamilyen okból kifolyólag nem kapnak diplomát (Eurostat 2016). Ezért egy olyan országos szintü lemorzsolódás ellen stratégiát kell kialakítani, melybe a felsőoktatási intézmények meghatározó szerepet vállalnak, egyrészt a lemorzsolódással veszélyeztetett hallgatók jellemzőről, a lemorzsolódás okait vizsgáló kutatásokkal, mely megalapozhatja azokat a beavatkozási területeket és módszereket, mely hatásos lehet a felsőoktatást érintő lemorzsolódás csökkentésében. A lemorzsolódás csökkentésében az alábbi föbb feladatokat fogalmaztuk meg a kutatási eredményeinkből.

1. A kontakt órákon való részvételi arány motiválása stratégiai kérdés a lemorzsolódás csökkentése érdekében, hiszen az óráktól való távolmaradás elősegítheti a lemorzsolódást. Az óralátogatások motivációját be kell építeni a tanulmányaikat megkezdő diákok regisztrációs heti és gólyatábori programjaiba.

2. A lemorzsolódás elleni stratégiában fontos szerepet kell, hogy kapjon a hallgatók egészségtudatos magatartásának kialakítása, melyben a káros szenvedélyektől való tartózkodás vagy az azt befolyásoló protektív tényezők (mint.pl. a sportolás) ösztönzése is meg kell jelenjen. Kutatásunk során ugyanis beigazolódott, hogy az egészségtudatos hallgatók között az óralátogatás és a tanulási motiváció, a feladatvégzés a legjobb eredményt hozta. Így a stratégiában központi szerepet kell, hogy kapjon a hallgatók egészségtudatos magatartásának formálása, a felvilágosítás.

3. Mivel a kutatásunk azt igazolta, hogy a rizikó-magatartással jellemezhető hallgatói csoport tagjai érték el a legrosszabb értéket több vizsgált paraméterben, így fontos a káros szenvedélyek elleni küzdelem és prevenció. A káros szenvedélyek (alkohol, drog, cigaretta) esetében vannak olyan protektív, azaz védő tényezők, melyek mellett kisebb a valószínúsége annak, hogy a szerhasználat kialakul (Müller és Kovács 2018). Ilyen védő tényező lehet a magas tanulmányi motiváció, a hosszútávú tervek megléte, a kortárscsoport olyan tagjai, akik elutasítják a szerhasználatot, a pozitív iskolai viszonyulás, demokratikus iskolai környezet segítő csoporttársak és tanárok. Így a lemorzsolódás elleni stratégiában központi szerepet kell, hogy kapjon ezeknek a protektív tényezőknek a beépítése.

4. A sportolás az egészségtudatos életmód szerves része, de talán erre külön is hangsúlyt kell fektetni. Motiválni és ösztönözni kell a hallgatókat a rendszeres testedzésre, sportolásra. Egyrészt, mert védő tényező a szerhasználat egyes formáival szemben, másrészt mert a tanulmányi teljesítményt, eredményességet is javíthatja. A sportolás védő-, illetve támogató faktor jellegét a felsőoktatásban több hazai egyetemi kutatás is alátámasztotta (Kovács 2015b; 2015c, Lenténé 2015). A sportoló hallgatók arányát növelni kell, ösztönözni öket a rendszeres mozgásra. A vízió ezen a területen a „Sportoló Egyetem” elérése, melynek fó célja, hogy legyen a sport minden hallgató szenvedélye.

5. A kutatásunk azt is megmutatta, hogy a tanulásra fordított idő és az extrakurrikuláris tevékenységek (beadandó dolgozatok, elolvasott szakköny- 
vek) csupán szükséges, de nem elégséges feltételei a sikeres vizsga teljesítésének. A vizsgára való felkészítés a lemorzsolódás elleni stratégia szerves részét kell, hogy képezze. Egyrészt a tanulást támogató módszerek ismertetése, esetleg oktatása lehet fontos, másrészt a vizsgaszituációból fakadó stresszhelyzet kezelése stressz-oldó módszerek alkalmazásával, valamint vizsgaszituáció modellálásával segítheti a hallgatókat.

\section{Felhasznált irodalom}

1. Aszmann A. (1997): Életmód, életkörülmények. Főiskolai egyetemi hallgatók életkörülményei, közérzetük és egészséget befolyásoló magatartásuk. In Som F. (szerk.): Felsőoktatás, Értelmiség, Egészség. Budapest, MEFS. 80-105.

2. Aquilina, D. (2013): A Study of the relationship between elite athletes' educational development and sporting performance. The International Journal of the History of Sport, 30. 4: 374-392.

3. Borbély Attila, Müller Anetta (2008): A testi-lelki harmónia összefüggései és módszertana. In dr. Koncz I. (szerk.): Valóság-Térkép-6. PEM tanulmányok. Budapest, Professzorok az Európai Magyarországért Egyesület. 54-55.

4. Bourdieu, P. (1977): Reproduction in Education, Society, Culture. Sage. Beverly Hills, Calif.

5. Cnaan, R. A., Goldberg-Glen, R. S. (1991): Measuring motivation to volunteer in human services. Journal of Applied Behavioural Sciences, 27, 3: 269-284.

6. Cranford, J. A., Eisenberg, D., Serras, A. M. (2009): Substanceuse behaviors, mental health problems, and use of mental health services in a probability sample of college students. Addictive Behaviors, 34: 134-145.

7. Czeglédi L. (2017a): Digitális repozitóriumok szerepe és lehetőségei a felsőoktatásban. In Karlovitz J. T. (szerk.): Válogatott tanulmányok a pedagógiai elmélet és szakmódszertanok köréböl. Komárno, International Research Institute. 395-400.

8. Czeglédi L. (2017b): Adaptív tanulási környezetek könyvtári támogatása. In Nádasi A. (szerk.): Agria Media 2017: „A digitális átállás a tanulást élménnyé teszi”. Eger, Líceum Kiadó. 11-15.

9. Czeglédi L. (2018): Digital collections in physical education (PE). In J. Šimonek, B. Dobay (szerk.): Sport science in motion: proceedings from the scientific conference. Športová veda v pohybe: recenzovaný zborník vedeckých a odborných prác z konferencie. Komárno: Univerzita J. Selyeho. 244-251.

10. Daley, F. (2010): Why College Students Drop out and What We Do about It. College Quarterly, 13. 3: 1-5.

11. De Knop, P., Wylleman, P., Van Hoecke, J., De Martalaer, K., Bollaert, L. (1999): A European Approach to the Management of the Combination of Academics and Elite-Level Sport. Perspectives. The Interdisciplinary series of Physical Education and Sport Science: School Sports and Competition 1: 49-62. 
12. DiMaggio, P. (1982): Cultural Capital and School Success: The Impact of Status Culture Participation on the Grades of U. S. High School Students. American Sociological Review, 47: 189-201.

13. Emmons, K. M., Wechsler, H., Dowdall, G., \& Abraham, M. (1998): Predictors of smoking among US college students. American Journal of Public Health, 88: 104-107.

14. Engler Á. (2012): Férfiak és nők a felsőoktatás részidős képzéseiben. Felsőoktatási Mühely, 5. 1: 95-106.

15. Engler Á. (2014): Hallgatói metszetek. A felsőoktatás felnőtt tanulói. Debreceni Egyetem, Debrecen.

16. Epple, D., Romano, R. E. (1998): Competition between Private and Public Schools, Vouchers, and Peer-Group Effects. American Economic Review, 88. 1: 33-62.

17. Eurostat (2016): More and more persons aged 30 to 34 with tertiary educational attainment in the EU http:/ec.europa.eu/ eurostat/ documents/ 2995521/ 7242558/3-27042016-AP-EN.pdf/ 83c2d88c-9ba8-47d7-8caf-8d765585967a. Last accessed: 19 March 2018.

18. Fényes H. (2010): A nemi sajátosságok különbségének vizsgálata az oktatásban. A nők hátrányainak felszámolódása? Debrecen, Debreceni Egyetemi Kiadó.

19. Fényes H., Markos V. (2016): Az intézményi környezet hatása az önkéntességre. In Pusztai G., Bocsi V., Ceglédi T. (szerk.): A felsőoktatás (hozzáadott) értéke: Közelítések az intézményi hozzájárulás empirikus megragadásához. Budapest, Nagyvárad, Partium, Új Mandátum, PPS. 248-261.

20. Fényes H., Kovács K., Dusa, Á. R., Fekete A., Kardos K., Kovács E., Márkus Zs., Morvai L., Nagy Z., Sebestyén K. (2015): Felsőoktatásban résztvevő hallgatók különböző kompetenciáinak mérési lehetőségei. In Pusztai G., Kovács K. (szerk.): Ki eredményes a felsőoktatásban? Nagyvárad, Partium Press. 66-78.

21. Forray R. K., Juhász E. (szerk.) (2009): Nonformális - informális - autonóm tanulás. Debrecen, Debreceni Egyetem.

22. Hanson, M. D., Chen, E. (2007): Socioeconomic status and health behaviors in adolescence: a review of the literature. Journal of Behavioral Medicine, 30, 3: 263-285.

23. Hegedűs, R. (2016): Számok-arányok-mintázatok a felsőoktatásba felvett hátrányos helyzetüek esetében. Modern Geográfia, 3: 1-14.

24. Hsieh, Ch., Urquiola M. (2006): The Effects of Generalized School Choice on Achievement and Stratification: Evidence from Chile's Voucher Program. Journal of Public Economics, 90. 8-9: 1477-1503.

25. Hunt, J., Eisenberg, D. (2010): Mental health problems and help-seeking behavior among college students. Journal of Adolescent Health, 1: 3-10.

26. Jaya J., Birthal, P. S. (2017): Does consumption of tobacco and alcohol affect household food security? Evidence from rural India. Food Security, 9, 2: 255-279.

27. Koncz K. (2006): Női karrieresélyek, karriertípusok s karrierjellemzők. Munkaügyi Szemle, 50, 9: 28-35.

28. Kopp M. (2010): A gender kutatások népegészségügyi és demográfiai jelentősége. Mentálhigiéne és Pszichoszomatika, 4: 243-254. 
29. Kozsla T., Bardocz B., Farkas J. (2014): A sportolói kettős karrier elmélete és gyakorlata. Nemzetközi és európai gyakorlatok feltérképezése és az uniós iránymutatások hazai implementációja. Támop 6.1.2/11/2-2012-02. kódszámú: A fizikai aktivitás és a sport magyarországi dimenzióinak feltárása c. projekt tanulmánya. Budapest, Magyar Sportmenedzsment Társaság.

30. Kovács K. (2013): Bourdieu, Hradil és Bandura elméleteinek vizsgálata a sportra vonatkozóan. A társadalmi, környezeti és egyéni tényezők hatása a partiumi régió hallgatóinak sportolására. Társadalomkutatás, 2: 175-194.

31. Kovács K. (2015a): Magyarországi és romániai hallgatók sportolási szokásait meghatározó szocio-kulturális tényezők. In Kozma T., Kiss V. Á., Jancsák Cs., Kéri K. (szerk.): Tanárképzés és oktatáskutatás. Debrecen, Magyar Nevelés- és Oktatáskutatók Egyesülete. 673-685.

32. Kovács K. (2015b): A sportolás hatása a tanulmányi eredményekre. In Pusztai G., Kovács K. (szerk.): Ki eredményes a felsőoktatásban? Nagyvárad, Budapest, Partium Press, Personal Problems Solution, Új Mandátum Kiadó. 161-171.

33. Kovács K. (2015c): A sportolás mint támogató faktor a felsőoktatásban. Oktatáskutatók könyvtára 2. Debrecen, CHERD.

34. Kovács K., Lenténé Puskás A., Moravecz M., Rábai D., Bácsné Bába É. (2017): A sportolás intézményi különbségei hazai és határon túli kisebbségi magyar felsőoktatási intézményekben. PedActa, 7, 2: 19-34.

35. Kun Zs., Szretykó, Gy. (2011): Karriermenedzsment a magyar élsportban (1. rész). Humánpolitikai Szemle, 5: 3-17.

36. Leathwood, C. (2006): Gender, Equity and the Discourse of the Independent Learner in Higher Education. Higher Education, 52. 4: 611-633.

37. Lenténé Puskás A. (2014): A Debreceni Egyetem és a hozzá tartozó sportszervezetek kapcsolat-és müködési rendszerének változásai 2000-2013 között. Agrártudományi közlemények - Acta Agraria Debreceniesis, 58: 133-139.

38. Lenténé Puskás A. (2015): The connection between academic and athletic performance among elite university student athletes. APSTRACT - APPLIED STUDIES IN AGRIBUSINESS AND COMMERCE, 9. 3: 19-26.

39. Lenténé Puskás A. (2016): A karriertervezés dimenziói és a sport iránti elkötelezettség változásai élsportoló egyetemi hallgatók körében. Taylor, 8. 3: 143-150.

40. Lenténé Puskás A. (2017): A sportolói karrier és a tanulmányok összehangolásának lehetőségei és kihívásai a Debreceni Egyetemen. Phd disszertáció. Debreceni Egyetem, Debrecen. https://dea.lib.unideb.hu/dea/bitstream/handle/ 2437/234797/Lentene_Puskas_Andrea_ertekezes_titkositott.pdf?sequence=1\&i sAllowed $=\mathrm{y}$

41. Mayer J. (2011): A korai iskolaelhagyás és társadalmi következményei. Új Pedagógiai Szemle, 61. 10: 18-29.

42. McKenna, J., Dunstan-Lewis, N. (2004): An Action research approach to supporting elite student-athletes in higher education. European Physical Education Review, 10. 2: 179-198.

43. Miller, P., Kerr, G. (2002): The athletic, academic and social experiences of intercollegiate studentathletes. Journal of Sport Behavior, 25. 4: 346-367.

44. Miller, R. L. (2000): Researching life stories and family histories. London, Sage Publ. 
45. Miller, J. W., Naimi, T. S., Brewer R. D., Jones, S. E. (2007): Binge drinking and associated health risk behaviors among high school students. Pediatric, 119, 1: 76-85.

46. Morstain, B. R., Smart, J. C. (1977): A Motivational Typology of Adult Learners. The Journal of Higher Education 48. 6: 665-679.

47. Mueller, M. W. (1975): Economic determinants of volunteer work by women. Journal of Women in Culture and Society, 1: 325-335.

48. Müller A., Kovács K. (2018): Testi-, lelki egészségre nevelés a pedagógiai gyakorlatban - felső tagozat. Jegyzet. Debreceni Egyetem.

49. OECD (2012): Equity and Quality in Education: Supporting Disadvantaged Students and Schools. http://dx.doi.org/10.1787/9789264130852. Last accessed: 15 March 2018.

50. O'Malley, P. M., Johnston, L. D. (2002): Epidemiology of alcohol and other druguse among American college students. Journal of Studies on Alcohol, Supplement, 14: 23-39.

51. Pikó, B. F., Brassai L., Fitzpatrick, K. M. (2013): Social Inequalities in SelfPerceived Health: Comparing Hungarian and Ethnic Minority Adolescents from Transylvania, Romania. European Journal of Mental Health, 8. 1: 29-45.

52. Pusztai, G., Ceglédi, T. (2015): Teacher Education Students in Central and Eastern Europe. In Pusztai, G., Ceglédi, T. (Eds.): Professional calling in higher education. Challenges of teacher education in the Carpathian Basin. Debrecen, Oradea, Partium Press, Persional Problems Solution, Új Mandátum. 7-11.

53. Sherry W K., James M L. III (2001): Who are student athletes? New Directions for Student Services, 93: 7-18.

54. Smith, S. D. H. (1994): Determinants of voluntary association participation and volunteering: A literature review. Nonprofit and Voluntary Sector Quarterly, 23. 3: 243-263.

55. Steptoe, A., Wardle, J., Cui, W., Bellisle, F., Zotti, A. M., Baranyai, R., Sanderman, R. (2002): Trends in smoking, diet, physical exercise, and attitudes toward health in European university students from 13 countries, 19902000. Preventive Medicine, 35. 2: 97-104.

56. Veroszta Zs. (2009): A hallgatói tanulási stratégiák sokfélesége. Diplomás Pályakövetés 2009 hallgatói véleményfelmérésének eredményei alapján. Felsőoktatási Mühely, 3. 3: 27-60.

57. Wechsler, H., Dowdall, G. W., Davenport, A., Castillo, S. (1995): Correlates of college student binge drinking. American Journal of Public Health, 85. 7: 921-926.

58. Wichstrøm, L. (1998): Alcohol intoxication and school dropout. Drug and Alcohol Review, 17. 4: 413-421.

59. Von Ah, D., Ebert, S., Ngamvitroj, A., Park N., Kang, D. H. (2004): Predictors of health behaviours in college students. Journal of Advanced Nursing, 48. 5: 463-474.

60. Wolfgang, E. M., Dowling, D. W. (1981): Differences in motivation of adult and younger undergraduates. The Journal of Higher Education, 52. 6: 640-648. 